\title{
Strategi pengembangan ekowisata mangrove Bandar Bakau Dumai, Riau
}

\author{
Aras Mulyadi*, Efriyeldi, Burhan Marbun \\ Universitas Riau Kampus Bina Widya KM. 12.5 Sp. Panam Pekanbaru \\ *Koresponden E-mail: aras.mulyadi@lecturer.unri.ac.id
}

(Diterima 30 November 2020|Disetujui 21 Januari 2021|Diterbitkan 30 Januari 2021)

\begin{abstract}
Bandar Bakau Mangrove Ecotourism is one of the most attractive natural tourist destinations in Dumai City. As a reference for future development, this study aims to analyze the mangrove ecotourism development strategy of Bandar Bakau Dumai. Surveys to collect primary data have been carried out in the field and on managers of Bandar Bakau Mangrove Ecotourism in June - November 2020. Meanwhile, secondary data were collected from the Dumai City Government and related literature. The data collected were analyzed descriptively, and to formulate a development strategy carried out using a SWOT analysis approach (Strengths, Weaknesses, Opportunities, Threats) from the identification of Internal factors (IFAS) and external factors (EFAS). To make mangrove ecotourism in Bandar Bakau Dumai a natural tourism place that can compete in the future, 4 (four) development strategies have been formulated, namely: 1) Development of Supporting and Supporting Facilities for Mangrove Ecotourism in Bandar Bakau Dumai, 2) Development of Mangrove Ecotourism Products in Bandar Bakau Dumai, 3) Strengthening the Role of Stakeholders in the Development of Mangrove Ecotourism in Bandar Bakau Dumai, and 4) Development of Conservation and Environmental Mitigation of Mangrove Ecotourism in Bandar Bakau Dumai.
\end{abstract}

\section{Keywords: Dumai, mangrove ecotourism, development, strategy}

Kota Dumai merupakan satu diantara daerah otonom yang berkembang dengan baik di Provinsi Riau. Sumberdaya alam yang menjadi keunggulan Kota Dumai adalah bidang pertanian, perkebunan, perikanan, hidrokarbon dan mineral. Keanekaragaman sumberdaya alam ini telah menjadikan Kota Dumai sebagai daerah industri dan perdagangan. Kedua sektor ekonomi ini telah menjadi tumpuan pembangunan daerah ini sejak lama. Beberapa tahun terakhir, Pemerintah Kota Dumai juga telah mulai mengembangkan bidang pariwisata. Kunjungan wisata di Kota Dumai tiga tahun terakhir telah terjadi fluktuasi yang sangat berbeda. Data \& Informasi Kota Dumai (2020) telah mencatat bahwa terjadi peningkatan kunjungan wisatawan dari 42.080 menjadi 46.590 pada kurun waktu 2017-2018, dan menurun tajam menjadi 35.177 orang pada tahun 2019.

Waktu tempuh dari Pekanbaru ke Dumai yang semula 4 sampai 5 jam, namun dengan adanya aksesibilitas jalan tol Pekanbaru-Dumai (tol PERMAI) sepanjang $131 \mathrm{~km}$ yang telah diresmikan pada pertengahan tahun 2020 lalu, waktu tempuh telah menjadi 1 jam 30 menit. Terbukanya akses jalan ini, diperkirakan akan berpengaruh langsung terhadap kunjungan wisatawan ke Kota Dumai. Tambahan lagi, di Kota Dumai setidaknya sudah didukung oleh fasilitas akomodasi sejumlah 29 penginapan dan hotel (Data \& Informasi Kota Dumai, 2020).

Sejalan dengan semakin intensifnya Pemerintah Kota Dumai dalam mengembangkan sektor pariwisata, penelitian tentang kajian pengembangan ekowisata Kota Dumai sangat tepat dilaksanakan. Ekowisata mangrove merupakan satu bentuk pembangunan wisata di Kota Dumai yang menjanjikan untuk dikembangkan. Dengan potensi keanekaragaman mangrove dan sumberdaya alam yang ada, Lembaga Swadaya Masyarakat Pencinta Alam Bahari (LSM PAB) Dumai telah mulai merintis tempat ekowisata mangrove Bandar Bakau Dumai. Tempat ekowisata mangrove Bandar Bakau Dumai telah mulai berbenah menuju menjadi lebih baik dalam menarik pengunjung untuk datang berwisata. Untuk itu, pembangunan ekowisata mangrove Bandar Bakau Dumai memerlukan perhatian serius. Data dan penelitian tentang ekowisata mangrove Bandar Bakau Dumai dengan berbagai permasalahan pengembangannya masih sangat terbatas. Atas dasar itu maka penelitian ini dilakukan dengan tujuan untuk menganalisis strategi pengembangan ekowisata mangrove Bandar Bakau Dumai. Dengan harapan, hasil penelitian ini dapat dijadikan sebagai dasar dalam pengembangan ekowisata yang berwawasan lingkungan di Kota Dumai.

\section{BAHAN DAN METODE}

Penelitian telah dilakukan pada bulan Juni sampai November 2020 di Kota Dumai, Riau, bertempat di kawasan ekowisata mangrove Bandar Bakau (Gambar 1). Pengumpulan data primer dilakukan dengan metoda survei melalui sampling lapangan dan wawancara dengan pengelola tempat ekowisata mangrove Bandar Bakau. Sedangkan data sekunder diperoleh dari Pemerintah Kota Dumai dan literatur-literatur terkait. Untuk merumuskan strategi pengembangan ekowisata mangrove Bandar Bakau Dumai telah dilakukan metoda pendekatan analisis SWOT (Strengths, Weakness, Opportunities, Threats), yaitu dari data yang dijabarkan diidentifikasi berbagai faktor Internal (IFAS): kekuatan (S) dan kelemahan (W) dan faktor Eksternal (EFAS): peluang (O) dan ancaman (T) (Rangkuti, 2001). 


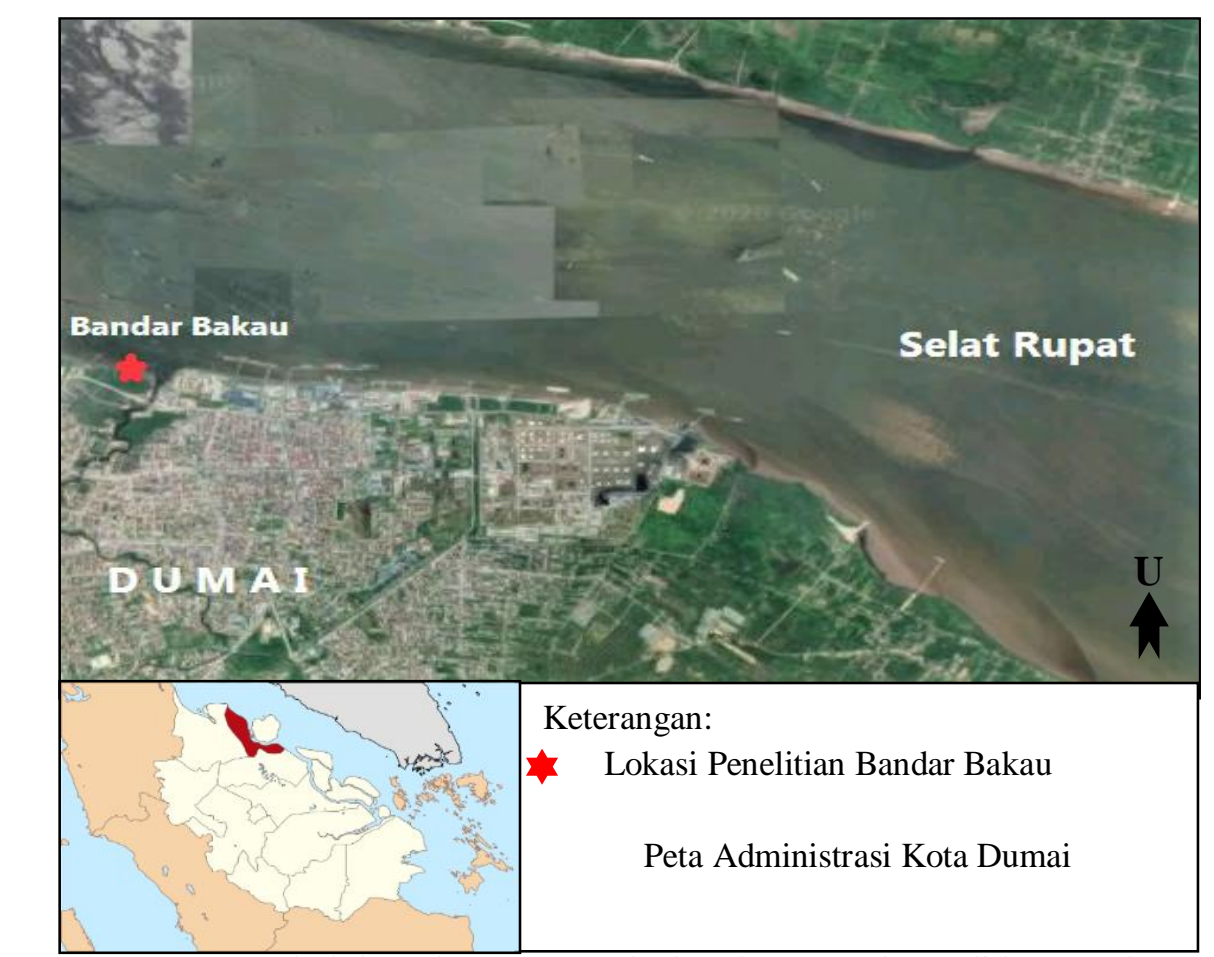

Gambar 1. Peta Administrasi Kota Dumai Riau dan Lokasi Penelitian Bandar Bakau Dumai (Sumber: https://id.wikipedia.org/ dan Google Map (diakses 20/10/2020)).

\section{HASIL DAN PEMBAHASAN}

\section{Analisis Faktor Internal (IFAS) dan Faktor Ekternal (EFAS)}

\section{Faktor Kekuatan (Strengths)}

Peraturan Daerah Kota Dumai Nomor 15 Tahun 2019 tentang Rencana Tata Ruang Wilayah Kota Dumai Tahun 2019-2039.

Kawasan ekowisata mangrove Bandar Bakau Dumai memiliki luas $31 \mathrm{Ha}$ dan yang baru dikelola 13 Ha, berada di kuala Sungai Dumai. Kawasan Bandar Bakau Dumai, awalnya merupakan kawasan pengembangan Pelindo. Dengan terbitnya tiga aturan perundang-undangan telah mempertegas status lahan ekowisata mangrove Bandar Bakau Dumai sebagai Hutan Produksi Terbatas. Ketiga aturan tersebut adalah Peraturan Daerah Kota Dumai Nomor 15 Tahun 2019 tentang Rencana Tata Ruang Wilayah Kota Dumai Tahun 2019-2039, yang merupakan bentuk turunan implemetasi dari Peraturan Daerah Provinsi Riau Nomor 10 Tahun 2018 tentang Rencana Tata Ruang Wilayah Provinsi Riau Tahun 2018-2038, dan Surat Keputusan Mentri Lingkungan Hidup dan Kehutanan Nomor 903 Tahun 2016 tentang Tata Ruang Riau.

Kawasan Bandar Bakau Dumai ini lokasinya sangat strategis, dekat dengan pusat kota, jalan menuju lokasi sudah bagus sehingga aksesnya mudah dan lancar, dekat dengan pelabuhan Pelindo, pelabuhan Perikanan, dan berseberangan dengan Pulau Rupat.

\section{Komitmen Pengelola LSM PAB}

Kawasan Bandar Bakau Dumai merupakan daerah yang ditumbuhi oleh hutan mangrove. Informasi yang didapatkan dari pengelola ekowisata mangrove Bandar Bakau bahwa di sekitar tahun 1998, hutan mangrove di kawasan ini kondisinya dalam keadaan rusak berat karena abrasi dan ancaman pasang surut serta dimanfaatkan oleh masyarakat secara tidak baik, seperti kayunya ditebang untuk keperluan sehari-hari, kebutuhan bahan bangunan, pembuatan arang dan oleh aktivitas perambahan lainnya.

Memperhatikan hal tersebut, LSM Pencinta Alam Bahari (LSM PAB) mengajukan izin pengelolaan kepada Pemerintahan Kota Dumai. Atas dasar persetujuan itu maka LSM PAB mempertahankan kawasan hutan mangrove ini sebagai daerah konservasi. Asbullah (2020) telah mengidentifikasi bahwa ada 5 (lima) program yang dilaksanakan LSM PAB dalam mempertahankan kawasan ekosistem mangrove Bandar Bakau Dumai: a) Sekolah Alam Bandar Bakau; b) Bank Mangrove; c) Aksi bersih sungai dan pantai; d) Aktivitas masyarakat berbasis lingkungan, dan e) Eksplorasi kawasan konservasi menjadi destinasi wisata (ekowisata mangrove).

Sebagai bukti tingginya komitmen LSM PAB dalam mengelola kawasan ekowisata mangrove Bandar Bakau, LSM PAB telah mendapat perhargaan lingkungan dari berbagai lembaga, diantaranya sebagai Kelompok Pelestarian Lingkungan, Adibakhti Minabahari, dan Kader Konservasi Terbaik. 


\section{Potensi Keragaman Mangrove}

Potensi objek dan daya tarik wisata di Bandar Bakau Dumai terutama bersumber dari kekayaan vegetasi mangrove. Dijumpai sebanyak 17 jenis mangrove sejati, yaitu: Avicennia marina (api-api jambu), Avicennia alba (api-api putih), Bruguiera gymnorriza (tumu), Bruguiera parviflora (lenggadai), Ceriops tagal (tengar), Heritiera littoralis (dungun), Lumnitzera littorea (teruntum, sesop merah), Lumnitzera racemora (susup, teruntum bunga putih), Nypa frutican (nipah), Rhizophora apiculata (bakau, bakau kecil, bakau putih), Rhizophora mucronata (bakau, belukap, bakau kurap), Rhizophora stylosa (bakau, bakau merah), Scyphiphora hydrophyllacea (cingam), Sonneratia alba (prepat), Sonneratia ovata (kedabu), Xylocarpus granatum (nyirih) dan Acrostrichum sp (piai). Penelitian Asbullah (2020) juga menemukan sebanyak 22 jenis mangrove asosisasi di Bandar Bakau Dumai meliputi Akasia mangium (akasia), Calophylum inophylum (gurah), Cerbera manghas (bintan, buta-buta), Clerodendrum inerme (kayu tulang, keranji), Derris trifolia (tuba laut), Ficus microcarpa (beringin, kayu ara), Flacourtia rukam (rukam), Flagellaria indica (rotan dini, rotan tikus), Gymnanthera paludosa (kacang-kacang, kacang laut) Hibiscus tiliaceus (waru), Ipomea pes-caprae (katangkatang, daun barah), Melastoma cadidum (senduduk), Morinda citrifolia (mengkudu), Pandanus tectorius (pandan laut), Pandanus odoratissima (pandan tikar), Sesuvium portulacastrum (rumput gelang), Spinefex littoreus (gulung-gulung), Stachytarpheta jamaicensis (ekor kuda), Terminalia cattapa (ketapang), Thespesia populne (waru laut), Vitex pubescens (leban kampung), dan Wedelia biflora (serunai laut).

Vegetasi mangrove memiliki keunikan, dimana mangrove hanya hidup pada habitat berlumpur dan sangat dipengaruhi oleh air pasang surut dan kadar garam. Dengan struktur perakaran beragam: a) akar pasak/akar napas (pneumatophores), b) akar lutut (kneeroots), c) akar tunjang (stilt -roots), d) akar papan (plankroots), e) akar gantung (aerial-roots); dan g) akar banir (buttress), telah membedakan vegetasi mangrove dengan tumbuhan lain yang hidup di daratan (Mulyadi, 2017). Penampilan perakaran demikian, selain bentuk adaptasi dari tumbuhan mangrove, juga telah menjadi daya tarik bagi pengunjung hutan mangrove untuk mengeksplornya. Rerimbun pepohonan mangrove juga membuat udara menjadi sejuk dan nyaman untuk berlindung berada di bawah naungannya. Kebutuhan akan udara bersih dan jauh dari keramaian menjadi pilihan suasana nyaman yang dicari oleh pengunjung di sekitar ekosistem mangrove.

\section{Faktor Kelemahan (Weakness)}

\section{Terbatas Pembiayaan dari Pengelola}

Masalah pembiayaan menjadi permasalahan tersendiri bagi pengelola tempat ekowisata mangrove Bandar Bakau Dumai. Sumber keuangan untuk pengelolaan Bandar Bakau Dumai berasal dari pendapatan sendiri, selain juga berasal dari donatur dan hasil kerjasama dengan pihak pemerintah, swasta dan masyarakat. Pendapatan sendiri diperoleh dari hasil penjualan bibit mangrove dan penjualan tiket masuk kedalam kawasan ekowisata mangrove Bandar Bakau. Menurut pengelola Bandar Bakau bahwa harga penjualan bibit mangrove senilai Rp. 5.000,- per batang dan biaya masuk per pengunjung dikenakan biaya sebesar Rp. 5000,- per orang. Hasil penjualan bibit mangrove dan tiket masuk digunakan untuk biaya operasional, perlindungan dan pengelolaan lingkungan, serta perawatan sarana prasarana. Kerjasama antara LSM PAB selaku pengelola dengan pihak pemerintah dan swasta telah tercatat, antara lain dengan pemerintah Provinsi Riau dan Pemerintah Kota Dumai (melalui Dinas terkait), PT. CPI, PT. Pertamina (Persero), PT. Pelindo dan perusahaan swasta lainnya. Menurut informasi dari pengelola Bandar Bakau Dumai bahwa bantuan pihak swasta disalurkan berupa program Community Developmet (CD) dan Corporate Social Responsibility (CSR) dalam bentuk kegiatan seperti pembangunan gedung dan sarana prasarana penunjang lainnya.

\section{Fasilitas Pendukung dan Penunjang Masih Kurang}

Fasilitas pendukung dan fasilitas penunjang merupakan faktor penentu dalam pengembangan suatu kawasan ekowisata. Fasilitas pendukung ekowisata yang sudah tersedia di Bandar Bakau Dumai, antara lain: rumah makan (1 unit), warung/kedai (7 unit), gerai (8 unit), gedung utama (1 unit), home stay (1 unit), gedung perpustakaan Perpustakaan Intan Payung (1 unit), balai keluarga/gazebo sejumlah (41 unit), meja santai tanpa payung (12 unit), pelataran atau jetty (panjang $200 \mathrm{~m} \times$ lebar $1 \mathrm{~m}$ ), serta fasilitas seni dan budaya. Fasilitas pendukung ini selain jumlahnya yang masih kurang jika dibandingkan dengan luas kawasan yang tersedia, kondisinya sebagian besar juga dalam kondisi tidak terawat dan memerlukan perhatian serius. Bahkan beberapa fasilitas pendukung yang mestinya ada, tapi belum dimiliki oleh Bandar Bakau Dumai (Tabel 1).

Demikian juga dengan fasilitas penunjang seperti toilet, mushalla, pusat informasi dan pusat cendera mata, jumlahnya belum memadai. Lapangan parkir baik untuk kendaraan roda dua maupun mobil seluas $20 \mathrm{~m}$ x $20 \mathrm{~m}$ masih perlu dilakukan pembenahan. Fasilitas penunjang lain seperti papan penunjuk arah, papan nama jenis mangrove dan teropong juga belum dijumpai di lokasi Bandar Bakau Dumai.

\section{Kegiatan Ekowisata Masih Terbatas}

Potensi daya tarik wisata di Bandar Bakau Dumai berasal dari keanekaragaman mangrove, keanekaragaman fauna, panorama dan keindahan laut, serta kuliner. Seiring dengan masih minim dan kurang bagusnya kondisi fasilitas pendukung dan fasilitas penunjang, maka potensi daya tarik ekowisata Bandar Bakau Dumai juga masih belum maksimal pengembangannya.

Kegiatan wisata yang banyak dilakukan pengunjung saat ini adalah menikmati panorama alam dan laut, sambil menikmati minuman dan kuliner di 
warung, gazebo/balai keluarga dan meja santai tanpa payung. Sedangkan kegiatan wisata memanfaatkan keanekaragaman vegetasi mangrove, udara sejuk dan nyaman, swafoto dan jelajah di kawasan mangrove masih belum termanfaatkan secara optimal. Begitu juga dari daya tarik Bandar Bakau sebagai penyimpan sumberdaya lingkungan dan megabiodiversitas juga masih minim dimanfaatkan, terutama perannya baik sebagai pusat pendidikan dan pelatihan, maupun sebagai pusat penelitian dan informasi ilmiah.

Tabel 1. Distribusi dan Status Fasilitas Pendukung dan Fasilitas Penunjang Ekowisata Bandar Bakau Dumai.

\begin{tabular}{|c|c|c|c|c|c|c|}
\hline \multirow[t]{2}{*}{ No } & \multirow[t]{2}{*}{ Jenis Fasilitas } & \multirow{2}{*}{$\begin{array}{l}\text { Jumlah/Belum } \\
\text { Ada }\end{array}$} & \multicolumn{4}{|c|}{ Kondisi } \\
\hline & & & Baik & Cukup & $\begin{array}{l}\text { Belum } \\
\text { Cukup }\end{array}$ & $\begin{array}{l}\text { Tidak } \\
\text { Terawat }\end{array}$ \\
\hline \multicolumn{7}{|c|}{ Fasiltas Pendukung } \\
\hline 1. & Sekolah Alam & 1 unit & Baik & Cukup & & \\
\hline 2. & Gedung Utam/kantor & 1 unit & Baik & Cukup & & \\
\hline 3. & Home Stay & 1 unit & & & $\begin{array}{l}\text { Belum } \\
\text { Cukup }\end{array}$ & $\begin{array}{l}\text { Tidak } \\
\text { Terawat }\end{array}$ \\
\hline 4. & Perpustakaan & 1 unit & & Cukup & & $\begin{array}{l}\text { Tidak } \\
\text { Terawat }\end{array}$ \\
\hline 5. & Gazebo/Balai Keluarga & 41 unit & & & $\begin{array}{l}\text { Belum } \\
\text { Cukup }\end{array}$ & $\begin{array}{l}\text { Tidak } \\
\text { Terawat }\end{array}$ \\
\hline 6. & Meja Santai Tanpa Payung & 12 unit & & & $\begin{array}{l}\text { Belum } \\
\text { Cukup }\end{array}$ & $\begin{array}{l}\text { Tidak } \\
\text { Terawat }\end{array}$ \\
\hline 7. & Rumah Makan & 1 unit & Baik & Cukup & & \\
\hline 8. & Warung/Kedai & 7 unit & Baik & & $\begin{array}{l}\text { Belum } \\
\text { Cukup }\end{array}$ & \\
\hline 9. & Gerai & 8 unit & & & $\begin{array}{l}\text { Belum } \\
\text { Cukup }\end{array}$ & $\begin{array}{l}\text { Tidak } \\
\text { Terawat }\end{array}$ \\
\hline 10. & Pelataran/jatty & $\begin{array}{l}\text { Panjang } 200 \\
\text { meter }\end{array}$ & & & $\begin{array}{l}\text { Belum } \\
\text { Cukup }\end{array}$ & $\begin{array}{l}\text { Tidak } \\
\text { Terawat }\end{array}$ \\
\hline 11. & Fasilitas Seni/Budaya & 1 unit & Baik & Cukup & & \\
\hline 12. & Anjungan Penanaman & Ada & Baik & Cukup & & \\
\hline 13. & Menara Pantau & Belum Ada & & & & \\
\hline 14. & Perahu atau Kano & Belum Ada & & & & \\
\hline 15 & Workshop Pembibitan & Belum Ada & & & & \\
\hline Fasi & as Penunjang & & & & & \\
\hline 16. & Toilet & 2 unit & & & $\begin{array}{l}\text { Belum } \\
\text { Cukup }\end{array}$ & $\begin{array}{l}\text { Tidak } \\
\text { Terawat }\end{array}$ \\
\hline 17. & Mushallah & 1 unit & Baik & & $\begin{array}{l}\text { Belum } \\
\text { Cukup }\end{array}$ & \\
\hline 18. & Pusat Informasi & 1 unit & Baik & Cukup & & \\
\hline 19. & Pusat Cindera Mata & 1 unit & Baik & Cukup & & \\
\hline 20. & Area Parkir & $20 \mathrm{~m} \times 20 \mathrm{~m}$ & & & $\begin{array}{l}\text { Belum } \\
\text { Cukup }\end{array}$ & $\begin{array}{l}\text { Tidak } \\
\text { Terawat }\end{array}$ \\
\hline 21. & Tempat Sampah & Tidak dihitung & & & $\begin{array}{l}\text { Belum } \\
\text { Cukup }\end{array}$ & $\begin{array}{l}\text { Tidak } \\
\text { Terawat }\end{array}$ \\
\hline 22. & Pos Tiket & 1 Unit & Baik & Cukup & & \\
\hline 24. & Papan Nama Lokasi & Ada & Baik & & $\begin{array}{l}\text { Belum } \\
\text { Cukup }\end{array}$ & \\
\hline 23. & Petunjuk Arah & Belum Ada & & & & \\
\hline 25. & $\begin{array}{l}\text { Papan Nama Jenis } \\
\text { Mangrove }\end{array}$ & Belum Ada & & & & \\
\hline 26. & Teropong & Belum Ada & & & & \\
\hline
\end{tabular}


Tambahan lagi bahwa Bandar Bakau juga dikitari oleh ekosistem sungai (sungai Dumai), ekosistem laut (selat Rupat), ruang terbuka dan juga dilintasi oleh jalan penghubung dari pusat kota Dumai ke kawasan-kawasan strategis disekitarnya. Ekosistem-

ekosistem dan akses jalan ini sangat potensial untuk dikembangkan menjadi kegiatan ekowisata, seperti susur pantai dan sungai, memancing (fishing), olah raga bersepeda (gowes), jogging, berkemah (camping), iven-iven budaya dan lainnya.

\section{Faktor Peluang (Opportunities)}

\section{Kawasan Konservasi Mangrove di Kota Dumai}

Tempat ekowisata mangrove Bandar Bakau Dumai menjadi satu alternatif wisata bagi para pengunjung, tertutama yang menyukai minat wisata alam atau ekowsiata. Ekowisata adalah kegiatan pariwisata yang mengutamakan aspek konservasi alam, aspek pemberdayaan sosial budaya, ekonomi masyarakat lokal serta aspek pembelajaran dan pendidikan.

Tempat ekowisata mangrove Bandar Bakau Dumai memiliki kondisi ekosistem mangrove yang masih dikategorikan baik dengan keanekaragaman vegetasi dan fauna yang tinggi. Awalnya kawasan ini masih terancam oleh berbagai kegiatan pembangunan seperti perluasan kawasan pelabuhan Pelindo, pelayaran, pelabuhan rakyat dan pemukiman, namun belakangan sudah terjaga dengan baik. Kawasan mangrove Bandar Bakau Dumai menjadi benteng ekologis, fungsi biologis dan peran sosial ekonomis bagi daerah sekitar. Kawasan ini menjadi salah satu green belt bagi pantai Dumai dari ancaman abrasi dan intrusi air laut. Selain itu secara ekologis, kawasan mangrove Bandar Bakau Dumai juga berperan sebagai filter sedimen dan bahan pencemar yang masuk ke perairan laut, sebagai sumber stock karbon dan sebagai lahan terbuka hijau untuk paru-paru Kota Dumai. Selain itu, juga mempunyai arti penting sebagai habitat tempat hidup bagi flora dan fauna sehingga berperan sebagai penyimpan biodiversitas pesisir yang beragam.

Di Bandar Bakau Dumai juga telah berdiri Sekolah Alam Bandar Bakau (SABB). SABB bertujuan untuk menanamkan rasa kepedulian dan tanggungjawab masyarakat sejak dini dalam menjaga dan melestarikan lingkungan pesisir dan mangrove. SABB telah melaksanakan pembelajaran dalam bentuk tatap muka dan praktek lapangan tentang lingkungan mangrove dan pesisir, seperti kegiatan pengumpulan biji, pembenihan dan pembibitan, penanaman dan pemeliharaan tumbuhan mangrove. Bandar Bakau telah menjadi pusat pembibitan mangrove yang dapat menyuplai keperluan bibit di daerah Dumai dan sekitarnya. Ada beberapa jenis mangrove yang telah dikembangkan pembibitannya di kawasan Bandar Bakau Dumai seperti Rhizophora sp, Avicennia sp, Bruguiera sp dan Sonneratia sp.

\section{Meningkatkan Ekonomi Masyarakat Sekitar}

Telah teridentifikasi beberapa fasilitas dan bentuk kegiatan di tempat ekowisata mangrove Bandar Bakau Dumai, yang diperkirakan dapat meningkatkan ekonomi masyarakat sekitar, terutama melalui peluang usaha dan peluang kerja. Toko souvenir dan beberapa rumah makan, kantin, kedai dan pedagang penjaja dengan berbagai jenis makanan telah berkembang dengan baik. Kegiatan ini dilakukan oleh keluarga pengelola dan relawan serta masyarakat di sekitar Bandar Bakau. Makanan yang dijual mulai dari menu makan utama dan menu sarapan seperti lontong dan mie instan, makanan ringan, kue-kue kering, kue basah dan minuman seperti teh, kopi, juice dan kelapa muda. Dari hasil berjualan diperoleh pendapatan tidak kurang dari Rp.100.000-250.000 per orang per hari. Penelitian Asbullah (2020) juga telah mencatat bahwa ekowisata mangrove Bandar Bakau Dumai memberi dampak ekonomi langsung bagi masyarakat lokal sekitar Rp. 2.400.000-3.000.000,- per bulan. Peluang kerja seperti karyawan rumah makan dan kedai, tukang parkir juga sudah terbuka bagi masyarakat sekitar. Penjaga pintu masuk dan pemandu wisata telah diberdayakan oleh pengelola melalui kelompok Sadar Wisata (Pokdarwis) yang ada.

\section{Partisipasi Stakeholders}

Berdirinya tempat ekowisata mangrove Bandar Bakau Dumai telah membuka peluang bagi stakeholders untuk dapat berpartisipasi, baik secara langsung maupun tidak langsung. Bentuk partisipasi langsung yang dapat dilakukan oleh stakeholders antara lain dalam bentuk sharing budget untuk pengembangan sarana dan prasarana, serta kegiatan ekowisata di Bandar Bakau. Telah tercatat beberapa pihak swasta seperti PT. Pertamina, PT. Pelindo, PT. CPI dan perusahaan lainnya telah memberikan kontribusi dalam pengembangan sarana dan prasarana Bandar Bakau Dumai. Pada tahun 2010, Pemerintah Provinsi Riau telah membangun pelantaran atau jetty sebagai fasilitas penunjang ekowisata di Bandar Bakau, namun beberapa waktu belakangan, kondisinya sudah sangat memprihatinkan dan rusak. Kemudian pada tahun 2020, PT. Pertamina-Integrated Terminal Dumai telah melakukan pengembangan pelantaran atau jetty di Bandar Bakau Dumai sepanjang $200 \mathrm{~m}$ dan lebar $1 \mathrm{~m}$. Selain itu, tercatat juga bahwa Institut Agama Islam Tafaqquh Fid-din Dumai juga telah berpartisipasi dalam pembangunan mushallah di Bandar Bakau Dumai.

Partisipasi dari berbagai stakeholders dalam bentuk penelitian, pendidikan, pelatihan dan penghijauan juga telah tercatat dengan baik. Berbagai satuan pendidikan dari jenjang Taman Kanak-kanak, SD, SMP, SMA, Perguruan Tinggi, perorangan, lembaga pemerintah, perusahaan dan organisasi sosial telah ikut serta dalam kegiatan tersebut di tempat ekowisata Bandar Bakau Dumai.

Bentuk aksi nyata peluang kawasan Bandar Bakau Dumai sebagai kegiatan konservasi mangrove telah diwujudkan dalam bentuk kegiatan penanaman 
mangrove dan "Pohon Tokoh". Penelitian Asbullah (2020) mencatat bahwa hingga tahun 2018 telah dilakukan penanaman mangrove sebanyak 53.648 batang di Bandar Bakau Dumai. Kegiatan ini telah dilakukan oleh berbagai instansi pemerintah dan swasta, baik dari dalam maupun luar Kota Dumai seperti lembaga pendidikan (mulai dari TK dampai Perguruan Tinggi), Pemerintah Provinsi Riau, Pemenrintah Daerah Dumai, TNI, Polri, DPRD, LSM, dan Dunia Usaha serta beberapa dalam bentuk perorangan oleh orang tertentu.

\section{Faktor Ancaman (Threats)}

\section{Banjir Rob dan Abrasi Pantai}

Kota Dumai memiliki topografi sebagian besar disusun dataran rendah (0-25 meter dpl) pada bagian Utara, dan berhadapan langsung dengan Selat Rupat. Perairan selat Rupat merupakan perairan semi tertutup, memiliki gelombang dan arus yang dikendalikan oleh musim angin dan pasang surut dengan tipe pasang-surut campuran condong ke harian ganda. Dengan kondisi demikian, Kota Dumai kerap menjadi langganan banjir rob atau lebih dikenal masyarakat dengan sebutan "pasang keling". Banjir rob merupakan banjir yang airnya berasal dari naiknya pasang air laut hingga menggenangi daratan. Banjir rob telah tercatat mengancam keselamatan masyarakat bahkan dapat menghancurkan berbagai bentuk bangunan di sekitar pesisir Dumai. Tempat ekowisata mangrove Bandar Bakau juga telah menjadi langganan ancaman dari banjir rob.

Selain itu, abrasi juga merupakan ancaman serius bagi Kota Dumai. Ancaman yang terbesar terhadap pantai dan keberlangsungan pohon mangrove adalah abrasi yang masif. Memang belum ada data yang tersedia mengenai laju abrasi pantai di Kota Dumai, namun secara kasat mata, ancaman abrasi di daerah ini telah mengakibatkan terkikisnya bibir pantai dan hutan mangrove bahkan sampai ke pemukiman penduduk.

\section{Pengembangan Kota dan Alih Fungsi Hutan Mangrove}

Kota Dumai telah berkembang sebagai suatu daerah otonomi sebagai kota pelabuhan, perdagangan dan industri. Kondisi ini di satu sisi menjadi hal positif bagi daerah, namun di sisi lain juga menjadi ancaman bagi lingkungan. Alih fungsi hutan mangrove untuk kebutuhan pembangunan infrastruktur dan perluasan kota telah menjadi ancaman bagi kawasan Bandar Bakau. Selain itu, ancaman alih fungsi lahan di sekitar Bandar Bakau juga bersumber dari perluasan permukiman, perkebunan rakyat, dan pembangunan pelabuhan rakyat. Hal ini diperkuat oleh penelitian Mulyadi \& Amin (2016) bahwa ancaman terhadap hutan mangrove di sekitar Bandar Bakau antara lain berasal dari kegiatan transportasi laut, aktivitas pelabuhan ferry, pelabuhan kargo dan barang, permukinan, pembangunan jalan dan penebangan mangrove.

\section{Pencemaran Limbah Padat dari Kota Dumai}

Pencemaran limbah padat di kota Dumai sebagian besar bersumber dari limbah domestik perkotaan, yakni dari penduduk, hotel, restoran, pertokoan, rumah sakit, dan pasar. Pada tahun 2019 tercatat penduduk Kota Dumai sebesar 303.292 jiwa, dengan kepadatan $176 \mathrm{jiwa} / \mathrm{Km}^{2}$, dan laju pertumbuhan pada 2018-2019 sebesar 2,74\%. Dengan jumlah penduduk 303.292 jiwa dan faktor produksi limbah padat $150 \mathrm{~kg}$ /orang/tahun (standard WHO, US-AFA), maka diperkirakan limbah padat yang dihasilkan tidak kurang dari 45,49 ton/tahun dari Kota Dumai. Karakteristik limbah padat yang dihasilkan juga bervariasi. Mulyadi \& Amin (2016) telah mengidentifikasi bahwa limbah padat di kawasan mengrove Kota Dumai sebesar 35,00 satuan/100m², yang disusun oleh bahan plastik, kantong plastik, botol plastik, styriform, kayu dan karet. Selain itu, keberadaan kegiatan galangan kapal, pelabuhan rakyat, dan fasilitas pendukung di sekitar tempat ekowisata mangrove Bandar Bakau juga menjadi sumber limbah padat dan menjadi ancaman bagi kawasan ini. Pembuangan limbah padat ke hutan mangrove akan menimbulkan berbagai masalah terhadap lingkungan, baik berupa penurunan kualitas perairan maupun akan menggangu biota dan kesehatan tumbuhan magrove dan bahkan mati.

\section{Strategis Pengembangan Ekowisata Mangrove Bandar Bakau Dumai.}

Analisis silang antara Kekuatan (S), Kelemahan (W), Peluang (O) dan Ancaman (T) melalui pendekatan analisis SWOT (Tabel 2) telah merumuskan 4 (empat) strategi pengembangan Ekowisata Mangrove Bandar Bakau Dumai.

\section{Strategi Pertama: Pengembangan Fasilitas Pendukung dan Penunjang Ekowisata Mangrove Bandar Bakau Dumai.}

Strategi pertama ini merupakan hasil analisis silang antara W-O dan W-T. Kiatnya yakni memperkuat kelemahan yang dimiliki untuk mendapatkan peluang dan meminimalisir ancaman yang ada di Bandar Bakau Dumai. Menurut Joandani et al (2019), pengembangan sarana dan prasarana merupakan suatu hal yang sangat penting dalam kegiatan wisata agar setiap pengunjung yang datang mendapat kemudahan dan kenyamanan dalam berwisata. Merujuk kepada Tabel 1, dapat dilihat bahwa beberapa fasilitas pendukung dan fasilitas penunjang di tempat ekowsiata mangrove Bandar Bakau masih perlu pembenahan serta perlu diinisiasi pengadaan dan pengembangannya demi kenyamanan dan mempermudah pengunjung untuk berwisata. 
Tabel 2. Analisis SWOT dalam Merumuskan Stategi Pengelolaan Ekowisata Mangrove Bandar Bakau Dumai.

\begin{tabular}{|c|c|c|}
\hline FAKTOR INTERNAL & $\begin{array}{l}\text { KEKUATAN (S) } \\
\text { 1) Peraturan Daerah Kota Dumai } \\
\text { Nomor } 15 \text { Tahun } 2019 \text { tentang } \\
\text { Rencana Tata Ruang Wilayah Kota } \\
\text { Dumai Tahun 2019-2039 } \\
\text { 2) Komitmen Pengelola LSM PAB } \\
\text { 3) Potensi Keragaman Mangrove }\end{array}$ & $\begin{array}{l}\text { KELEMAHAN (W) } \\
\text { 1) Terbatas Pembiayaan dari } \\
\text { pengelola } \\
\text { 2) Fasilitas Pendukung dan } \\
\text { Penunjang Masih Kurang } \\
\text { 3) Kegiatan Ekowisata Masih } \\
\text { Terbatas }\end{array}$ \\
\hline $\begin{array}{l}\text { PELUANG }(\mathrm{O}) \\
\text { 1) Kawasan Konservasi } \\
\text { Mangrove di Kota Dumai } \\
\text { 2) Meningkatkan Ekonomi } \\
\text { Masyarakat Sekitar } \\
\text { 3) Partisipasi Stakeholders }\end{array}$ & $\begin{array}{l}\text { S-O } \\
\text { 1) Penguatan Peran Stakeholders dalam } \\
\text { Pengembangan Ekowisata Mangrove } \\
\text { Bandar Bakau Dumai } \\
\text { 2) Pengembangan Produk Ekowisata } \\
\text { Mangrove Bandar Bakau Dumai }\end{array}$ & $\begin{array}{l}\text { W-O } \\
\text { 1) Penguatan Peran Stakeholders } \\
\text { dalam Pengembangan Ekowisata } \\
\text { Mangrove Bandar Bakau Dumai } \\
\text { 2) Pengembangan Fasilitas } \\
\text { Pendukung dan Penunjang } \\
\text { Ekowisata Mangrove Bandar } \\
\text { Bakau Dumai } \\
\text { 3) Pengembangan Produk } \\
\text { Ekowisata Mangrove Bandar } \\
\text { Bakau Dumai }\end{array}$ \\
\hline $\begin{array}{l}\text { ANCAMAN }(\mathrm{T}) \\
\text { 1) Banjir Rob dan Abrasi Pantai } \\
\text { 2) Pengembangan Kota dan Alih } \\
\text { Fungsi Hutan Mangrove } \\
\text { 3) Pencemaran Limbah Padat } \\
\text { dari Kota Dumai }\end{array}$ & $\begin{array}{l}\text { S-T } \\
\text { Pengembangan Konservasi dan } \\
\text { Mitigasi Lingkungan Ekowisata } \\
\text { Mangrove Bandar Bakau Dumai }\end{array}$ & $\begin{array}{l}\text { W-T } \\
\text { Pengembangan Fasilitas } \\
\text { Pendukung dan Penunjang } \\
\text { Ekowisata Mangrove Bandar } \\
\text { Bakau Dumai }\end{array}$ \\
\hline
\end{tabular}

\section{Strategi Kedua: Pengembangan Produk Ekowisata Mangrove Bandar Bakau Dumai.}

Strategi kedua ini dirumuskan dari analisis silang antara S-O, W-O dan W-T. Melalui strategi ini, Bandar Bakau Dumai mesti senantiasa mengembangkan kekuatan dan menguatkan faktor kelemahan yang ada untuk memanfaatkan peluang dalam meminimalisir ancaman. Produk wisata merupakan daya tarik bagi pengunjung yang datang untuk menikmati ekowisata di suatu tempat. Produk ekowisata yang ditawarkan sesuai dengan potensi sumberdaya alam, fasilitas dan aksesibiltas yang tersedia. Potensi produk ekowisata mangrove Bandar Bakau Dumai sangat beragam, namun dalam pengembangannya masih terbatas. Potensi produk ekowisata mangrove yang dapat dikembangkan di Bandar Bakau Dumai dapat dikategorikan kepada 2 (dua) kelompok, yaitu: (1) Produk Ekowisata Minat Khusus Mangrove, dan (2) Produk Penunjang Ekowisata Mangrove.

Produk ekowisata minat khusus mangrove yang sudah ada di Bandar Bakau Dumai, seperti: menyusuri hutan mangrove sambil menikmati keindahan vegetasi dan suasana mangrove melalui pelataran/jatty (tracking), fotografi dengan latar keindahan dan keunikan vegetasi mangrove dan panorama keindahan alam (photoselfy), pengamatan satwa (animal watching), Pendidikan Pesisir/Sekolah Alam Bandar Bakau
(SABB), pelatihan dan penelitian mangrove (mangrove researche and education), penanaman mangrove dan pohon tokoh (mangrove tree plantation) dapat lebih dioptimalkan. Ke depan pengelola Bandar Bakau Dumai mungkin perlu menginisiasi pengembangan program minat khusus yang potensial di tempat ini, antara lain kegiatan bersampan menyusuri kawasan mangrove dan sungai Mesjid (canoeing and baoting), memancing (fishing), dan mangrove education and tour. Merujuk kepada penelitian Karlina (2015) bahwa program ekowisata minat khusus mangrove yang telah dikembangkan di kawasan pantai Tanjung Bara, Kutai Timur, Kalimantan Timur, seperti bird watching, animal watching, board walking, fishing, canoeing dan photografi. Sedangkan di Ngurah Rai Bali menurut Wahyuni et al (2006), program minat khusus mangrove yang paling disenangi adalah kegiatan mangrove education tour dan tracking, sedangkan kegiatan bird watching hanya diminati oleh kalangan tertentu karena memerlukan waktu yang tepat dan alat yang spesifik.

Produk penunjang ekowisata mangrove yang mungkin potensial untuk dikembangkan di sekitar Bandar Bakau Dumai, antara lain: menikmati panorama alam dan laut, melihat aktivitas masyarakat nelayan dan galangan kapal rakyat, kuliner dan souvenir, iven budaya, taman bermain, outbond atau camping (berkemah), olahraga jogging dan bersepeda (gowes). Dimana produk penunjang ekowisata 
mangrove tersebut dapat dikembangkan pada zona ruang terbuka di sekitar hutan mangrove, area parkir, aksesibiltas jalan dan tepi pantai. Menurut Joandani et al (2019), penempatan zona kegiatan ekowisata harus memperhatikan pemilihan kegiatan, alokasi sumberdaya alam dan alokasi ruang dengan memperhatikan aspek sumberdaya alam dan sumberdaya manusianya.

\section{Strategi Ketiga: Penguatan Peran Stakeholders dalam Pengembangan Ekowisata Mangrove Bandar Bakau Dumai.}

Strategi ketiga ini dirumuskan dari analisis silang antara S-O dan W-O. Stakeholder adalah sekelompok masyarakat yang memiliki hubungan dengan sebuah lembaga baik sebagai pihak mempengaruhi ataupun yang terpengaruh. Dimana hubungannya baik terkait dengan bidang ekonomi, sosial-budaya dan lainnya. Peran stakeholders merupakan aspek penting dan menjadi pilar utama dalam pengembangan ekowisata mangrove. Hal ini sejalan dengan pendapat Trisbiantoro \& Kusyairi (2018) dimana dalam pengembangan konservasi mangrove menjadi eco-wisata di Desa Banyuurip, Kecamatan Ujung Pangkah, Kabupaten Gresik sangat ditentukan oleh peran dan partisipasi dari berbagai stakeholders, diantaranya pemerintah Provinsi Jawa Timur, pemerintah Kabupaten Gresik, pemerintah desa Banyuurip, Perguruan Tinggi, pihak swasta, LSM, Kelompok Sadar Wisata, dan masyarakat.

Peran Pemerintah dalam pengembangan ekowisata mangrove Bandar Bakau Dumai, seperti juga dikemukan oleh Trisbiantoro \& Kusyairi (2018) antara lain dalam hal penyusunan kebijakan kepariwisataan dan promosi; kepastian tata ruang wilayah; peningkatan aksesibilitas ke tempat tujuan ekowisata; dan peningkatan kualitas sumberdaya manusia pelaku wisata, baik kuantitas maupun kualitas, dalam memberikan pelayanan dan pengembangan pariwisata daerah. Peran Dunia Usaha dapat membantu pengelola dalam membangun fasilitas ekowisata, dan pengembangan potensi objek dan daya tarik wisata (ODTW), yang dapat diimplementasikan dalam bentuk program Corporate Social Responsibility (CSR).

Peran Perguruan Tinggi dapat diwujudkan dalam bentuk penyediaan data melalui riset dan inovasi pengembangan, serta melakukan pendidikan dan pengabdian kepada masyarakat demi terciptanya ekowisata mangrove yang berkelanjutan. Lembaga non pemerintah (LSM) berperan lebih dominan dalam pendampingan dan penyuluhan akan pentingnya peranserta masyarakat dalam pembangunan ekowisata mangrove Bandar Bakau Dumai berbasiskan konservasi sumberdaya alam. Penelitian Joandani et al (2019) tentang konservasi mangrove sebagai pengembangan ekowisata di Desa Pasar Bangi, Rembang mengemukakan bahwa dukungan dari lembaga non pemerintah biasanya juga berupa kegiatan rehabilitasi dan sekaligus pengawasannya. Karena mayoritas pelaksanaan program rehabilitasi ekosistem mangrove hanya sampai kegiatan penanaman, padahal dengan adanya kegiatan monitoring, control dan evaluasi yang diprogramkan pasca penanaman akan memberikan peluang besar terpeliharanya mangrove yang telah ditanam.

Kelompok Sadar Wisata (Pokdarwis) merupakan salah satu komponen dalam masyarakat yang memiliki peran dan kontribusi penting dalam pengembangan kepariwisataan di daerahnya. Menurut Kemeterian Pariwisata dan Ekonomi Kreatif Republik Indonesia dalam Buku Pedoman Kelompok Sadar Wisata (2012), Pokdarwis ini merupakan kelompok swadaya dan swakarsa masyarakat yang dalam aktivitas sosialnya berupaya untuk: meningkatkan pemahaman kepariwisataan, meningkatkan peran dan partisipasi masyarakat dalam pembangunan kepariwisataan, meningkatkan nilai manfaat kepariwisataan bagi masyarakat/anggota Pokdarwis, dan mensukseskan pembangunan kepariwisataan.

\section{Strategi Keempat: Pengembangan Konservasi dan Mitigasi Lingkungan Ekowisata Mangrove Bandar Bakau Dumai.}

Strategi keempat ini dirumuskan dari analisis silang antara S-T. Jika ekowisata Bandar Bakau Dumai ingin lebih berkembang dan mampu bersaing di masa yang akan datang maka mesti perlu senantiasa memperkuat Strengths yang dimiliki dalam meminimalisir ancaman, melalui praktek-praktek konservasi dan mitigasi.

Degradasi hutan mangrove, selain dipicu oleh faktor alam tetapi juga sebagian besar disebabkan oleh aktivitas manusia (faktor antropogenik) seperti aktivitas penebangan untuk bangunan dan keperluan kayu bakar yang berlebihan, alih fungsi lahan untuk pengembangan pertanian dan perkebunan, perikanan budidaya, pemukiman, industri dan pengembangan kota. Ancaman dari faktor alam yang dominan di kawasan ekowisata mangrove Bandar Bakau Dumai adalah banjir rob dan abrasi pantai. Untuk meminimalisir ancaman alami dan agar kawasan ekowisata mangrove Bandar Bakau tetap berkelanjutan (sustainable) di masa datang, maka diperlukan pengembangan strategi konservasi dan mitigasi bencana.

Strategi konservasi dilakukan untuk tujuan mengusahakan terwujudnya kelestarian sumber daya alam hayati serta keseimbangan ekosistemnya sehingga dapat lebih mendukung upaya peningkatan kesejahteraan masyarakat dan mutu kehidupan manusia. Menurut Undang-undang Nomor 5 Tahun 1990 tentang Konservasi Sumber Daya Alam Hayati dan Ekosistem bahwa konservasi sumber daya hayati adalah pengelolaan sumber daya alam hayati yang pemanfaatannya dilakukan secara bijaksana untuk menjamin kesinambungan persediaannya dengan tetap memelihara dan meningkatkan kualitas keanekaragaman dan nilainya.

Mitigasi bencana menurut Peraturan Pemerintah Nomor 21 Tahun 2008 tentang Penyelenggaraan Penanggulangan Bencana adalah 
serangkaian upaya untuk mengurangi risiko bencana, baik melalui pembangunan fisik maupun penyadaran dan peningkatan kemampuan menghadapi ancaman bencana. Selanjutnya, menurut Diposaptono (2003) bahwa mitigasi bencana alam di wilayah pesisir dapat dilakukan dalam bentuk mitigasi struktural dan non struktural. Mitigasi strukural merupakan upaya untuk meminimalkan bencana yang dilakukan melalui konstruksi atau perubahan lingkungan fisik dengan menggunakan pendekatan teknologi. Sedangkan mitigasi non struktural adalah upaya dalam mengurangi risiko dengan cara memodifikasi perilaku manusia atau proses alam tanpa memerlukan struktur teknis.

\section{SIMPULAN}

Ekowisata mangrove Bandar Bakau Dumai memiliki kekuatan, kelemahan, peluang dan ancaman yang perlu mendapat perhatian untuk disiasati. Berdasarkan pendekatan analisis SWOT, telah dirumuskan 4 (empat) strategi pengembangannya, yaitu: 1) Pengembangan Fasilitas Pendukung dan Penunjang Ekowisata Mangrove Bandar Bakau Dumai, 2) Pengembangan Produk Ekowisata Mangrove Bandar Bakau Dumai, 3) Penguatan Peran Stakeholders dalam Pengembangan Ekowisata Mangrove Bandar Bakau Dumai, dan 4) Pengembangan Konservasi dan Mitigasi Lingkungan Ekowisata Mangrove Bandar Bakau Dumai

Pengembangan ekowisata mangrove Bandar Bakau Dumai diperlukan sebagai satu diantara faktor pengungkit pengembangan pariwisata di Kota Dumai. Untuk keberlanjutan pemanfaatannya, masih diperlukan kajian-kajian pengembangan, baik dari aspek kebijakan, kelembagaan, dan sumberdaya, serta dampak sosial budaya dan ekonomi pada masyarakat. Tambahan lagi, kajian lebih mendalam terhadap 4 (empat) strategi yang telah dirumuskan masih perlu dilakukan sehingga betul-betul dapat dijadikan sebagai acuan pengembangan ekowisata mangrove Bandar Bakau Dumai yang mampu bersaing di masa mendatang.

\section{UCAPAN TERIMA KASIH}

Penelitian ini dilakukan atas biaya dari DIPA Universitas Riau tahun 2020, untuk itu penulis mengucapkan terima kasih kepada Universitas Riau atas fasilitasi anggarannya. Selain itu penulis juga mengucapkan terima kasih kepada Pengelola Ekowisata Mangrove Bandar Bakau Dumai, Pemerintah Kota Dumai dan kepada semua pihak yang telah memberikan kontribusi dan informasi demi terlaksananya penelitian ini dengan baik. Semoga bermanfaat sebagai sumber informasi dan rujukan pembangunan di masa datang.

\section{DAFTAR PUSTAKA}

Asbullah. (2020). Pengembangan Model Pengelolaan Lingkungan Hidup Berbasis Sekolah Alam dalam Meningkatkan Kesadaran Lingkungan Siswa: Studi Kasus pada Sekolah Alam Bandar Bakau Kota Dumai. Disertasi pada Jenjang Doktor Program Studi Ilmu Lingkungan Program Pascasarjana Universitas Riau (Tidak Diterbitkan). 172 halaman.

Data \& Informasi Kota Dumai. (2020). Sumber: https://datin.dumaikota.go.id/ (diakses pada 05/10/2020)

Diposatono, S. (2003). Mitigasi Bencana Alam di Wilayah Pesisir Terpadu di Indonesia. Alami 8 (2): $10-8$

https://id.wikipedia.org. (2020).Kota Dumai. Sumber: Wikipedia: Ensiklopedia Bebas (diakses pada 015/10/2020).

Joandani, G.K., Pribadi, R., Suryono, C.A. (2019). Kajian Potensi Pengembangan Ekowisata sebagai Upaya Konservasi Mangrove di Desa Pasar Banggi, Kabupaten Rembang. Journal of Marine Research 8 (1): 117-126. https://doi.org/10.14710/jmr.v8i1.24337

Karlina, E. (2015). Strategi Pengembangan Ekowisata Mangrove di Kawasan Pantai Tanjung Bara, Kutai Timur, Kalimantan Timur. Jurnal Penelitian Hutan dan Konservasi Alam 12 (2): 191-208. https://doi.org/10.20886/jphka.2015.12.2.191-208

Kementerian Pariwisata \& Ekonomi Kreatif Republik Indonesia. (2012). Pedoman Kelompok Sadar Wisata. Dirjen Pengembangan Destinasi Pariwisata: 52 hal.

Mulyadi A., Amin, B. (2016). Vegetation Structure and Mangrove Ecosystem Threats in The Coastal Zone of Dumai, Riau, Indonesia. Intern. Journal App. Env Sci. 11 (3): 785-798.

Mulyadi, A. (2017). Mangrove Di Kampus Universitas Riau (Penulis Utama) - Edisi Revisi. Unri Press. 70 halaman.

Rangkuti, F. (2001). Analisis SWOT, Teknik Membedah Kasus Bisnis. Gramedia Pustaka Utama. Jakarta.

Trisbiantoro, D., Kusyairi, A. (2018). Peran dan Partisipasi Stakeholder dalam Pengembangan Konservasi Mangrove Menjadi Eco-wisata (Studi Kasus di Desa Banyuurip, Kecamatan Ujung Pangkah, Kabupaten Gresik. Makalah pada Prosiding Seminar Nasional Kelautan dan Perikanan IV 2018. Surabaya 05 Spetember 2018.

Wahyuni, P.I., Ardhana, I., Sunarta, I.N. (2006). Evaluasi Pengembangan Ekowisata di Kawasan Tahura Ngurah Rai, Bali. Jurnal Ecotrophic 4 (1): 49-56. 